\title{
Elektrikli Araçlar İçin Lityum İyon Bataryaların Modellenmesi
}

\author{
Muhammed Sefa ÇETINN ${ }^{1}$, Barış KARAKAYA ${ }^{2 *}$,Muhsin Tunay GENÇOĞLU ${ }^{3}$ \\ ${ }^{1}$ Elektrik-Elektronik Mühendisliği Bölümü, Mühendislik Fakültesi, Fırat Üniversitesi, Elazığg, Türkiye \\ ${ }^{2}$ Elektrik-Elektronik Mühendisliği Bölümü, Mühendislik Fakültesi, Fırat Üniversitesi, Elazığ, Türkiye \\ ${ }^{3}$ Elektrik-Elektronik Mühendisliği Bölümü, Mühendislik Fakültesi, Fırat Üniversitesi, Elazığ, Türkiye \\ ${ }^{1}$ 192113202@firat.edu.tr, ${ }^{* 2}$ bkarakaya@firat.edu.tr, ${ }^{3}$ mtgencoglu@firat.edu.tr
}

Öz: Son yıllarda, içten yanmalı motorlu araçların neden olduğu çevresel sorunların oldukça artması nedeniyle elektrikli araç teknolojisindeki gelişmeler hız kazanmıştır. Ancak elektrikli araçlar henüz içten yanmalı motorlu araçların yerini tam olarak alamamıştır. Çünkü elektrikli araçların menzil ve şarj süresi sorunları bulunmaktadır. Bu iki sorun batarya parametresi ile ilgilidir. Bu yüzden elektrikli araçlarla ilgili çalışmalar batarya gruplarına yoğunlaşmıştır. Bu çalı̧̧mada elektrikli araçlar ve batarya sistemleri incelenmiştir ve MATLAB/Simulink ortamında bir elektrikli araç için lityum iyon batarya paketi modellemesi yapılmıştır.

Anahtar kelimeler: Elektrikli araç, batarya, modelleme, lityum iyon.

\section{Modelling of Lithium Ion Batteries for Electric Vehicles}

\begin{abstract}
In recent years, developments in electric vehicle technology have accelerated due to the increase in environmental problems caused by internal combustion engine vehicles. However, electric vehicles have not yet completely replaced internal combustion engine vehicles. Because electric vehicles have range and charging time problems. These two problems are related to the battery unit. Therefore, studies on electric vehicles have focused on battery groups. In this study, electric vehicles and battery systems are examined. In addition, a lithium-ion battery pack modeling for an electric vehicle has been made in the MATLAB/Simulink environment.
\end{abstract}

Key words: Electric vehicle, battery, modelling, lithium ion.

\section{Giriș}

Çağımızdaki çevresel sorunlar ve içten yanmalı motorlu araçların bakım ve yakıtla ilgili sorunları, elektrikli araç teknolojisinin yaygınlaşmasını hızlandırmıştır. İlk olarak elektrik motoru ve içten yanmalı motorların birlikte kullanıldığı hibrit sistemlerle başlayan çalışmalar, batarya teknolojisindeki gelişmelerle birlikte araçların tamamen elektrikli olarak yani sadece elektrik motoru kullanılarak üretilmesine imkân tanımıștır.

Elektrikli araç sistemlerinde fosil yakıtlar kullanılmadığı ve yakıtın yanmasını sağlamak için içten yanmalı motora ihtiyaç duyulmadığı için bu sistemler hem daha ekonomik hem de daha çevrecidir. Ancak elektrikli araçların içten yanmalı motor teknolojisi kullanan araçlarla rekabet edebilmesi için düşük maliyet ve tam şarj menzili kriterlerinin istenen seviyeye gelmesi gerekmektedir. Ayrıca şarj esnasında şebekeden önemli miktarda güç çekildiği için, elektrikli araç sayısının artması şebeke üzerinde de olumsuz etki oluşturmaktadır [1].

Elektrikli araçların en önemli bileşenlerinden biri bataryadır. Çünkü bataryanın performansı doğrudan doğruya elektrikli aracın performansını etkilemektedir. Batarya tam şarj süresi, pil ömrü, menzil vb. kullanıcıların en önem verdiği kriterler doğrudan batarya sistemiyle ilgilidir. Elektrikli aracın hareketi için gerekli olan enerji, bataryada depolanan enerjiyle sağlanmaktadır. Bataryanın güvenli bir şekilde çalışması ve performansının zaman içinde kaybolmaması gerekmektedir. Bu nedenle elektrikli araçlarda bataryalar, batarya yönetim sistemi olarak adlandırılan sistemler ile yönetilmektedirler.

Elektrikli araçların yaygın kullanımının önündeki en büyük engellerden birisi üretim maliyetleridir. Bu nedenle elektrikli araçların maliyetini düşürme çalışmaları yapılmaktadır. Maliyeti oluşturan en önemli etkenlerden birisi batarya paketleridir. Bu yüzden elektrikli araçlar üzerine yapılan çalışmalar çoğunlukla batarya üzerine yoğunlaşmıştır. Batarya teknolojileri geliştirilmeye çalışılmakta ve elektrikli araçların batarya maliyeti sorunu ortadan kaldırılmaya çalışılmaktadır.

\footnotetext{
* Sorumlu yazar: bkarakaya@firat.edu.tr. Yazarların ORCID Numarası: ${ }^{1} 0000-0001-7995-3901,{ }^{2}$ 0000-0001-5587-0001, ${ }^{3}$ 0000-00021774-1986
} 
$\mathrm{Bu}$ çalışmada elektrikli araçlar ve elektrikli araçlarda kullanılan batarya sistemleri incelenmiş, elektrikli araçlar ile ilgili güncel bilgilere yer verilmiştir. Bataryalı elektrikli araçların çalışma prensipleri ve çeşitleri anlatılmıştır. Ayrıca elektrikli araçlarda kullanılan batarya sistemleri de detaylı olarak incelenmiştir. Elektrikli araçlarda kullanılan lityum iyon bataryaların MATLAB/Simulink ortamında modellemesi yapılarak benzetim sonuçları elde edilmiş̧ir.

\section{Bataryalı Elektrikli Araçlar}

Elektrikli araçlar, içten yanmalı motor kullanılmadan sadece elektrikli motor kullanılan araç türleridir. Bu araçlarda, araç hareketi ve motor tahriki pil paketlerinden (bataryalar) sağlanan elektrik enerjisiyle sağlanmaktadır [2]. Başlangıçta batarya maliyetlerinden ve düşük menzile sahip olmalarından dolayı geri plana atılan elektrikli araçlar, fosil yakıt rezervlerinin azalması ve petrolün bir küresel kriz haline dönüşüyor olmasından dolayı gündeme gelmiştir. İlk çalışmalar elektrikli araçların geleneksel içten yanmalı motorlu araçlarla rekabet edemeyeceğini göstermiştir. Ancak gelişen batarya teknolojisi sonucu, elektrikli araçlar içten yanmalı motorlu araçlarla rekabet edebilecek seviyeye gelmiştir. Özellikle hem çevresel hem de ekonomik ihtiyaçtan dolayı yoğunlaşan çalışmalar sonucu elektrikli araç kullanımını gittikçe yaygınlaşmaktadır.

Ülkemizde batarya ve elektrik enerjisini depolama alanında birçok sorun vardır. Batarya maliyetinin yüksek olması, hücre ve hammadde tedarikinin zor olması, tam şarj dolum sürelerinin uzun olması, batarya test ve güvenlik merkezlerinin bulunmaması, batarya ömrünün kısa olması ve garanti süreci aşamalarının netleştirilmemiş olması bu sorunlardan bazılarıdır [3]. Ülkemizde batarya kaynaklı sorunların yanı sıra şarj istasyonları konusunda da sorunlar bulunmaktadır. Denetleme kuralları ve standardının olmaması ve yüksek yatırım maliyetleri bunlardan bazılarıdır [3].

Elektrikli araçlar, motor tahriki için yakıta ihtiyaç duymadan, bataryada depolanan elektrik enerjisini kullanmaktadırlar. Bir elektrikli araç sadece elektrik motoru kullanır ve içten yanmalı motora ihtiyaç duymaz. Bataryadan alınan enerji elektrik motorunu tahrik eder. Motora verilecek akımın büyüklüğü ve yön kontrolü bir kontrol ünitesi kullanılarak gerçekleştirilir. Elektrikli motor, çıkış dönme hareketini diferansiyel kutusuna iletir. $\mathrm{Bu}$ kutu tekerleklerin dönüş hareketini sağlar. Elektrikli araçlar, çalışma prensibi en basit olan araçlardır [4]. Şekil 1 'de bir elektrikli aracın yapısı görülmektedir.

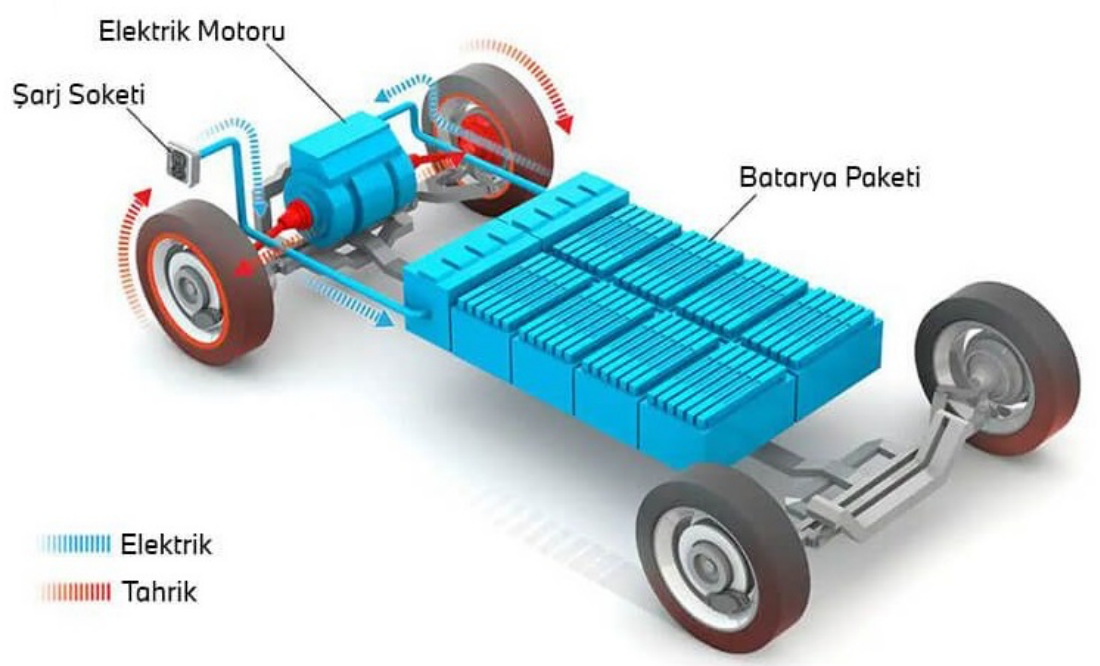

Şekil 1. Elektrikli aracın yapısı [5]

Elektrikli araçlarda çalışma prensibi gereği benzin, dizel veya diğer yakıtlar kullanılmadığından elektrikli araçlar fosil yakıt tüketmemekte ve emisyona da sebep olmamaktadırlar. Elektrikli araç bataryalarının şarjı esnasında tüketilen elektrik enerjisinin üretilmesinde oluşan zararlı emisyonlar, içten yanmalı motorlu araçlarla kıyaslandığında oldukça azdır [6]. 


\section{Elektrikli Araçlarda Batarya Sistemleri}

Bataryalar elektrik enerjisini kimyasal enerji olarak depolayan birimlerdir ve elektrik enerjisinin depolanmasını gerektiren taşınabilir elektronik cihazlar, telekomünikasyon altyapıları, yenilenebilir enerji sistemleri ve elektrikli araçlar vb. birçok alanda kullanılmaktadırlar [7]. Şekil 2'de elektrikli araçta lityum iyon batarya ve diğer birimler gösterilmektedir.

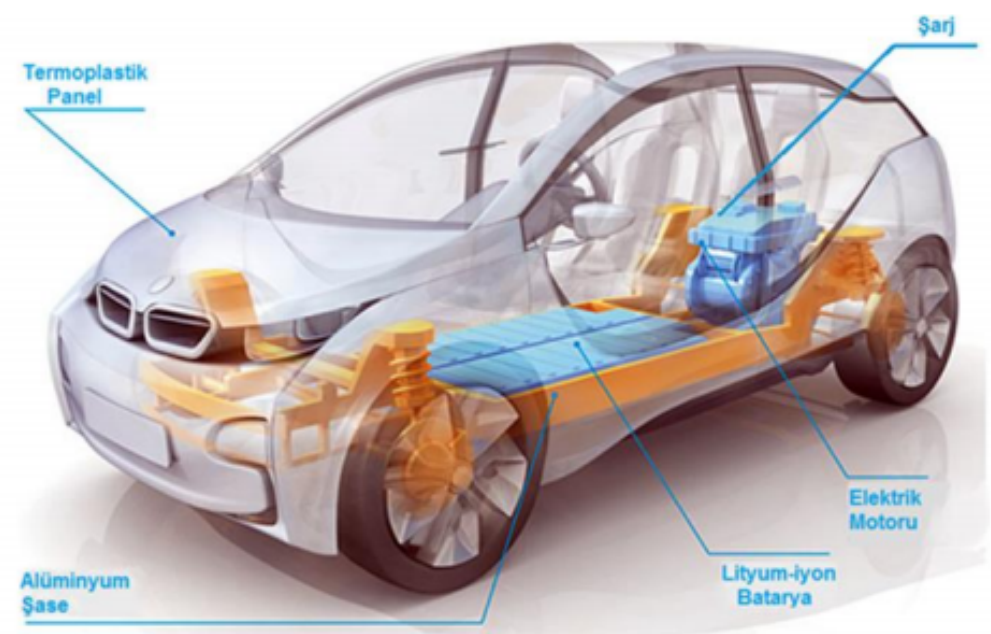

Şekil 2. Elektrikli araçta lityum iyon batarya ve diğer birimler [6]

Bataryalar, elektrokimyasal redoks tepkimesi aracılığıyla depo ettikleri kimyasal enerjiyi elektrik enerjisine dönüştürebilen bir çalışma sistemine sahiplerdir [8]. Şarj edilebilir bir sistem söz konusu olduğunda batarya tam tersi bir işlem ile şarj edilir. Bu tür bir tepkime, kullanılan bir elektrik devresi aracılı̆̆ılyla elektronların bir maddeden diğerine aktarılmasını kapsamaktadır. Paslanma veya yanma gibi tehlikelere sahip elektrokimyasal olmayan bir redoks tepkimesinde elektron aktarımı doğrudan yapılır. Bu nedenle bataryalar daha yüksek enerji dönüşüm verimliliğgine sahiptir [1].

Basit olarak bir batarya sistemi, istenilen çıkış gerilimini ve kapasiteyi elde edebilmek için seri, paralel veya hem seri hem de paralel kompleks bir şekilde bağlanmış, bir veya daha çok hücreden meydana gelmektedir. Her bir hücre ise; anot veya negatif elektrot, katot veya pozitif elektrot ve elektrolit olmak üzere üç ana bileşenden oluşmaktadır [1].

Bataryaların karakteristik özellikleri, bataryalarda kullanılan hücrelerin türü, hücrelerin sayısı, hücrelerin seri-paralel bağlantı yapısı ve bataryalarda kullanılan hücrelerin dışındaki donanımsal elemanlar tarafından belirlenir. Bir bataryada hücreler bir araya gelerek modülleri, modüller de bir araya gelerek bataryanın kendisini oluşturur [9].

Bataryalar, şarj edilebilir bataryalar ve şarj edilemeyen bataryalar olarak ikiye ayrılırlar. Şarj edilemeyen bataryalar "birincil bataryalar" olarak isimlendirilirken, şarj edilebilen bataryalar ise "ikincil bataryalar" olarak isimlendirilirler.

Şarj edilebilir yani ikincil bataryalar, deşarj olduktan sonra tekrar tam şarj edilerek kullanılabilen batarya türleridir. Aynı zamanda depolama bataryaları ve akümülatörler olarak da adlandırıllrlar [1]. İkincil bataryalar, yüksek güç yoğunluğu, yüksek deşarj oranı, düz deşarj eğrileri ve uygun düşük sıcaklık performansı ile karakterize edilirler [10]. Kurşun-Asit, Nikel Kadmiyum (Ni-Cd), Nikel Metal Hidrat (Ni-MH), Lityum İyon Polimer (LiPO) ve Lityum İyon (Li-ion) olarak sınıflandırılabilirler. Bu bataryaların en önemli özellikleri yüksek enerji yoğunluğuna sahip olmalarıdır [11].

Bataryalı elektrikli araçların geleneksel içten yanmalı motorlu araçlarla rekabet edebilmesi ve ileride yerini içten yanmalı motorlu araçların yerini alabilmesi için gerekli olan en kritik bileşen batarya gruplarıdır. Bataryaların en önemli ve en belirleyici özellikleri, enerji yoğunluğu (ağırllk/kg), güç yoğunluğu $(\mathrm{W} / \mathrm{kg})$, fiyat ve kullanım ömrüdür. Güç yoğunluğu ve enerji yoğunluğu harici parametrelerdir. Bu nedenle tam şarj olma ve tam deşarj olma süreleri kısa olan bir bataryanın uygun enerji saklama kapasitesi olamaz. Kullanım ömrü de kullanım ve şarj etme tarzına bağlıdır [12]. 
Piyasada bulunan elektrikli araçların bataryaları farklı sayıda hücrenin bir araya getirilmesi ile farklı özellikler kazanmışlardır. Bu farklı özellikler elektrikli araç tasarımlarında farklı bataryaların kullanılmasına sebep olmuştur [8]. Elektrikli araç üreticisi firmalar, elektrikli araç kullanıcılarının talepleri doğrultusunda uygun bir batarya seçerek aracı tasarlamaya çalışırlar.

\subsection{Elektrikli Araçlarda Kullanılan Batarya Teknolojileri}

Günümüzde farklı anma gerilimleri ve farklı enerji yoğunluklarına sahip çeşitli batarya teknolojileri mevcuttur. Elektrikli araçlarda yaygın olarak kullanılan bazı pil teknolojileri Tablo 1'de verilmiştir [13].

Tablo 1. Elektrikli araçlarda kullanılan batarya teknolojileri [13]

\begin{tabular}{cccccc}
\hline \hline Batarya Çeşitleri & $\begin{array}{c}\text { Nominal Gerilim } \\
(\mathrm{V})\end{array}$ & $\begin{array}{c}\text { Enerji } \\
\text { Yoğunluğu } \\
(\mathrm{Wh} / \mathrm{kg})\end{array}$ & $\begin{array}{c}\text { Çevrim } \\
\text { Ömrü } \\
(\#)\end{array}$ & $\begin{array}{c}\text { Hafıza } \\
\text { Etkisi }\end{array}$ & $\begin{array}{c}\text { Çalışma } \\
\text { Sıcaklığı } \\
\text { Aralığı }\left({ }^{\circ} \mathrm{C}\right)\end{array}$ \\
\hline \hline Pb-acid & 2 & 35 & 1000 & Yok & $-15-+50$ \\
\hline NiCd & 1.2 & $50-80$ & 2000 & Var & $-20-+50$ \\
\hline NiMH & 1.2 & $70-95$ & $<3000$ & Nadir & $-20-+60$ \\
\hline Zebra & 2.6 & $90-120$ & $>1200$ & Yok & $+245-+350$ \\
\hline Li-ion & 3.6 & $118-250$ & 2000 & Yok & $-20-+60$ \\
\hline LiPo & 3.7 & $130-225$ & $>1200$ & Yok & $-20-+60$ \\
\hline LiFePO & 3.2 & 120 & $>2000$ & Yok & $-45-+75$ \\
\hline Zn-air & 1.65 & 460 & 200 & Yok & $-10-+55$ \\
\hline Li-S & 2.5 & $350-650$ & 300 & Yok & $-60-+60$ \\
\hline Li-air & 2.9 & $1300-2000$ & 100 & Yok & $-10-+70$ \\
\hline \hline
\end{tabular}

Kurşun asit bataryaların yüksek deşarj akımı, hafıza etkisinin bulunmaması ve maliyetinin düşük olması gibi önemli avantajları bulunmaktadır. Ancak nominal gerilimi ve enerji yoğunlukları diğer batarya teknolojilerine göre düşüktür. Ayrıca kullanılmadıkları zaman batarya ömürleri düşmektedir [13]. Her bir kurşun asit batarya hücresi $2 \mathrm{~V}$ çıkış gerilimine sahiptir. Bu gerilim değeri hücre başına daha yüksek gerilim seviyesine sahip olan lityum iyon bataryalarla karşılaştırıldığında yetersiz kalmakta, aynı gerilim seviyesine sahip olmak için lityum iyon bataryalara göre daha çok sayıda kurşun asit batarya hücresinin kullanımını gerektirmektedir [11].

Nikel kadmiyum bataryalar uzun süreli raf ömrüne sahiptir. Çevrim başına fiyat karşılaştırması yapıldığında en ekonomik batarya türüdür. Nikel kadmiyum bataryaların belki de en büyük avantajı, uzun ömürlü olmaları ve fiziksel ve kimyasal tepkilere karşı daha dayanıklı olmalarıdır [14]. Diğer batarya türleriyle kıyaslandığında enerji yoğunlukları düşüktür. Hafıza etkisinin bulunması da en büyük yetersizliğidir. Hafıza etkisi, başka bir deyişle tembel pil etkisi nikel kadmiyum ve nikel metal hidrat ikincil bataryalarında görülmekte ve bu bataryaların daha az şarj tutmalarına sebep olmaktadır. Hafıza etkisi, nikel kadmiyum bataryaların deşarj olduktan sonra tekrar şarj edildikçe maksimum enerji kapasitelerini yavaş yavaş kaybettikleri durumu ifade eder. $\mathrm{Bu}$ durum özetle, bataryanın daha küçük bir batarya kapasitesini hatırlaması olarak açıklanabilir. Ayrıca nikel kadmiyum bataryalar, çevresel olarak dezavantajlara sahiptir. Enerji yoğunluğu bakımından kurşun asit bataryalara göre daha pahalı olması ve kadmiyum içermesi gibi yetersizlikleri vardır [15].

Nikel metal hidrat bataryalar, kadmiyum, kurşun veya cıva gibi zararlı maddeler içermediğinden kurşun asit ve nikel kadmiyum bataryalara kıyasla çevreye daha az zarar vermektedirler. Ayrıca maliyet bakımından lityum iyon pillere kiyasla daha uygundur [16].

Lityum iyon polimer bataryaların iletkenlikleri azdır ve bu yüzden yüksek sıcaklıklarda daha iyi performans sağlamaktadırlar. Lityum iyon bataryalarla karşılaştırıldığı zaman enerji yoğunluğu daha düşük ve çevrim sayısı daha az olmaktadır. Ancak nikel kadmiyum ve nikel metal hidrat bataryalara göre enerji yoğunlukları fazla ve kullanım ömürleri daha uzundur. Lityum iyon polimer batarya hücrelerinde katı lityum negatif elektrot bulunmasından dolayı güvenlik problemleri vardır ve metaldeki bozulmalardan dolayı performans düşüşleri görülebilir. Bu sebeple bu tip bataryaların yerini büyük ölçüde lityum iyon bataryalar almıştır [17]. 
Lityum sülfür bataryalar, enerji yoğunlukları yüksek, yüksek çevrim oranına sahip ve güvenli bir kullanıma sahip bataryalardır. Ancak bu bataryaların yerini avantaj ve üstünlükleri daha fazla olan lityum iyon bataryalar almıştır [13].

Batarya çeşitleri arasında, elektrikli araçlarda en yaygın olarak kullanılan batarya çeşidi lityum iyon bataryalardır. Lityum iyon bataryaların diğer batarya teknolojilerine göre üstünlükleri vardır ve bu nedenle elektrikli araçlarda da yaygın olarak kullanılmaktadırlar.

\subsection{Lityum İyon Bataryalar}

Lityum iyon bataryalar nikel tabanlı batarya gruplarıyla kıyaslandığında daha yüksek anma gerilim değerine ve daha yüksek enerji yoğunluğuna sahiptir [13]. Lityum iyon bataryalar günümüzde başta elektrikli araç uygulamalarında olmak üzere, elektronik cihazlarda ve birçok taşınabilir sistemde en çok tercih edilen batarya türüdür. Günümüzdeki teknolojiyle birlikte birim hücre başına en yüksek hücre gerilimi ve birim kütle başına en yüksek enerji yoğunluğuna sahip olan batarya çeşidi Lityum iyon bataryalardır. Bu bataryalar, hafiza etkisinin olmaması, kendi kendilerine deşarj olmalarının çok düşük oranda olması ve çevrim ömürlerinin yüksek olması bakımından diğer batarya çeșitlerinden üstündür [11]. Ayrıca lityum iyon bataryalar fiziksel olarak daha dayanıklıdır ve ortalama ömürleri beş yıldır. Diğer batarya türleri ile kıyaslandığı zaman en yüksek şarj verimine sahip batarya çeşitlerinden birisidir. Bunların yanı sıra lityum iyon batarya en az bakım gerektiren batarya türüdür.

Lityum iyon bataryalar, taşınabilir elektrokimyasal enerji depolamada ilk akla gelen kaynak olduğundan, performansı artırma uygulamalarını büyük ölçüde genişletebilmekte ve enerji depolamasına bağlı olarak yeni teknolojiler sağlayabilmektedir. Yeni malzemeler ve yeni stratejiler bulundukça, lityum iyon bataryaların gelecek yıllarda yaşam koşulları üzerinde şüphesiz daha fazla etkisi olacaktır [3].

\section{Modelleme ve Bulgular}

Benzetim çalışmaları, elektrikli araç sistemlerinin tasarımını kolaylaştırmaktadır. Benzetim yoluyla elektrikli aracın performansı ile ilgili tahminler yapılabilmektedir. Ayrıca elektikli aracın prototipi üzerinde iyileștirme çalıșması yapmaktan çok daha az maliyetli olacaktır [18].

Bu çalıșmada, MATLAB/Simulink ortamında, elektrikli araçlarda kullanılan lityum iyon batarya modelinin benzetimi yapılmıştır. Şekil 3'te MATLAB/Simulink modeli gösterilmektedir. Lityum iyon bataryalar; birim hücre başına en yüksek gerilim, birim kütle başına en yüksek enerji yoğunluğu, en az bakım gerektirme, yüksek çevrim ömrü üstünlüklerinden dolayı elektrikli araçlarda en yaygın kullanılan batarya türüdür.

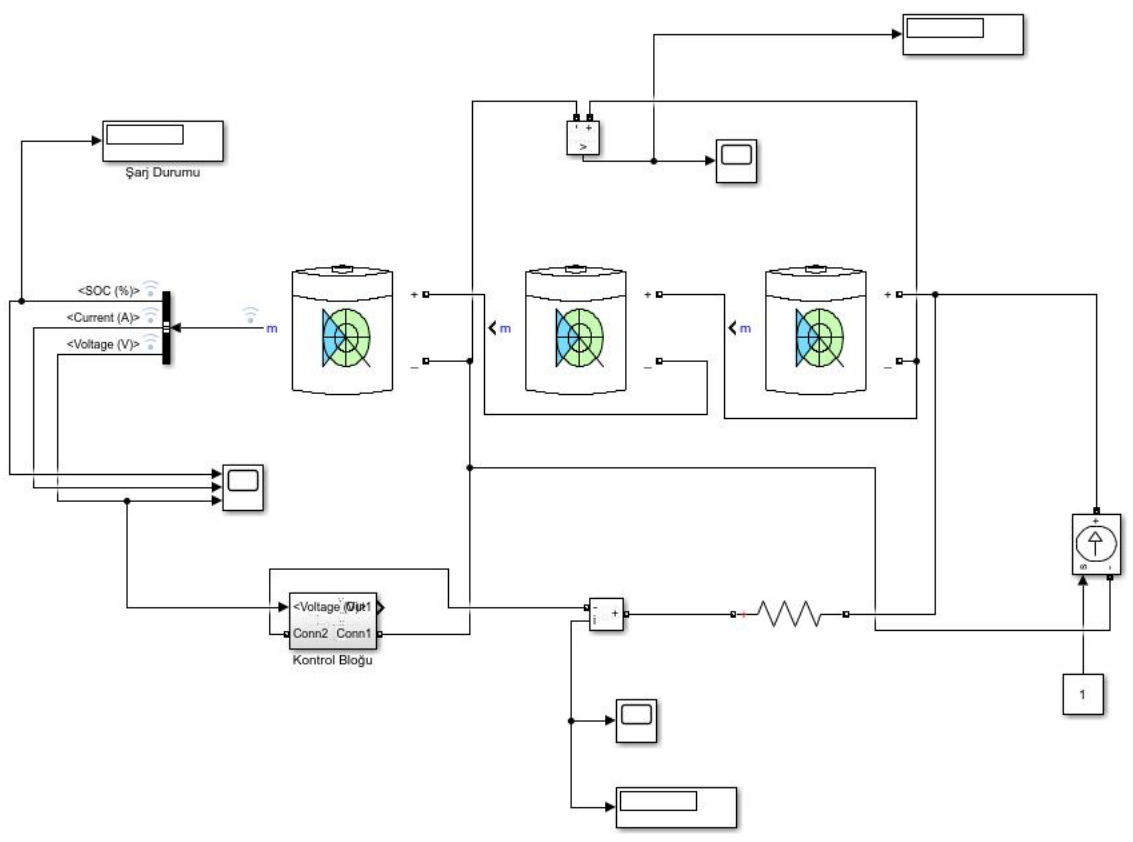

Sekil 3. Sistemin MATLAB/Simulink modeli 
$\mathrm{Bu}$ çalışmada; her bir bataryanın nominal gerilimi 3.7 V olarak belirlenmiştir [19]. Batarya minimum deşarj gerilimi $1.7 \mathrm{~V}$ olarak seçilmiş̧ir. Nominal deşarj akımı 2.3 A, nominal kapasitesi $4.8 \mathrm{Ah}$ ve maksimum kapasitesi 5.4 Ah olan üç adet seri bağl lityum iyon batarya kullanılmıştır. Batarya maksimum paket gerilimi 8.1 V'tur. Ayrıca akım, gerilim ve şarj durumu grafiklerinin sıfıra düştüğü anı tam olarak belirleyebilmek için bir güç elektroniği kontrol elemanı ve bataryanın deşarj süresi tahminini yapabilmek için seri bağlı yükler kullanılmıştır. Batarya paketinin şarjı için SASG (sabit akım-sabit gerilim) yöntemi kullanılmıştır. Deşarj olmadan önce batarya şarj durumu başlangıçta \%100'dür. Öncelikle başlangıçta sabit bir omik yük değeri için bataryanın şarj durumu, akım ve gerilim grafikleri elde edilmiştir. Yük değeri artırıldığında batarya deşarj sürelerinin nasıl değiştiği gözlenmiştir. Daha sonra devreye indüktif yükler eklenerek omik-indüktif yük durumu için batarya şarj durumu, akım ve gerilim grafikleri elde edilmiş̧ir. Batarya grubu sabit bir yük altındayken elde edilen sonuçlar Şekil 4'te verilmiştir. Yükün artırıldığı durumlar için elde edilen sonuçlar Şekil 5 ve Şekil 6'da gösterilmiştir.

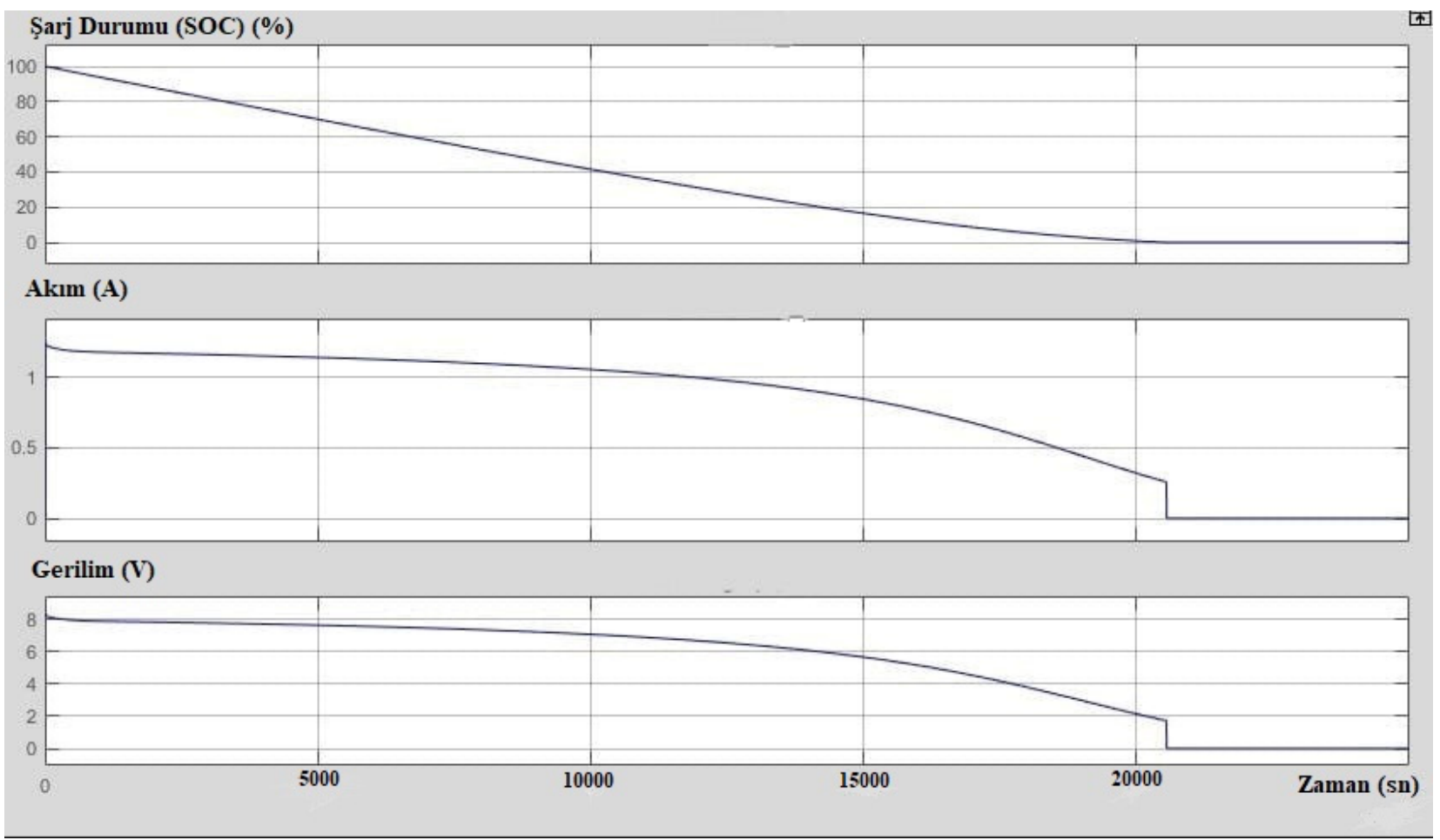

Şekil 4. Omik yük için akım, gerilim ve şarj durumu

Benzetim yapılmadan önce, yük artırıldığı zaman bataryanın deşarj süresinin kısalacağı öngörülmüștür. Benzetimle elde edilen SOC (şarj durumu) sonuçlarına bakıldığında da yük artırıldıkça bataryanın deşarj sürelerinin kısaldığı görülmüştür. Yani yük artırıldığı zaman bataryalar daha hızlı deşarj olmaktadır. Şekil 7'de devreye omik-indüktif yük bağlıyken batarya şarj durumu, akım ve gerilim grafikleri gösterilmektedir.

Şekil 4, sadece omik yük için elde edilen sonuçları gösterirken, Şekil 7 omik-indüktif bir yük için elde edilen sonuçları göstermektedir. Şekil 4 ve Şekil 7 elde edilirken kullanılan omik yük değerleri aynıdır. Batarya paketinin maksimum gerilimi 8.1 V'tur. Bu nedenle Şekil 4-7'de gerilim değerlerinin yaklaşık $8 \mathrm{~V}$ olduğu görülmektedir. İndüktif yükün şarj durumu, akım ve gerilime etkisinin incelenebilmesi amacıyla Şekil 4 ile Şekil 7 karşılaştırıldığında, SOC grafiğinden, devreye indüktif yük eklendiği zaman batarya deşarj süresinin neredeyse \%50 azaldığı görülmektedir. Gerilim değeri sabit kalırken akım değeri yaklaşık iki katına çıkmışıtır. Ayrıca gerilim değeri sıfıra düşmeden önce bir dalgalanma meydana gelmiştir ve omik yüklenme durumundan farklı olarak batarya tam deşarj olsa bile gerilim değeri tam olarak sıfır değerine ulaşmamıştır.

Şekil 4-7'den görüldüğü gibi, batarya minimum deşarj gerilimi olan $1.7 \mathrm{~V}$ değerinde deşarj sonlanmıştır. Böylece Lityum iyon bataryalarda minimum gerilimde deşarjın kesilmesi gerekliliği de sağlanmıştır. Ancak deşarj sonlanmasına rağmen benzetim devam ettiği için sonuçta Şekil 4-7'de gerilim değerinin sıfira indiği görülmektedir. Böylece deşarj sonlandıktan sonraki durumların incelenebilmesi de mümkün olmuştur. 

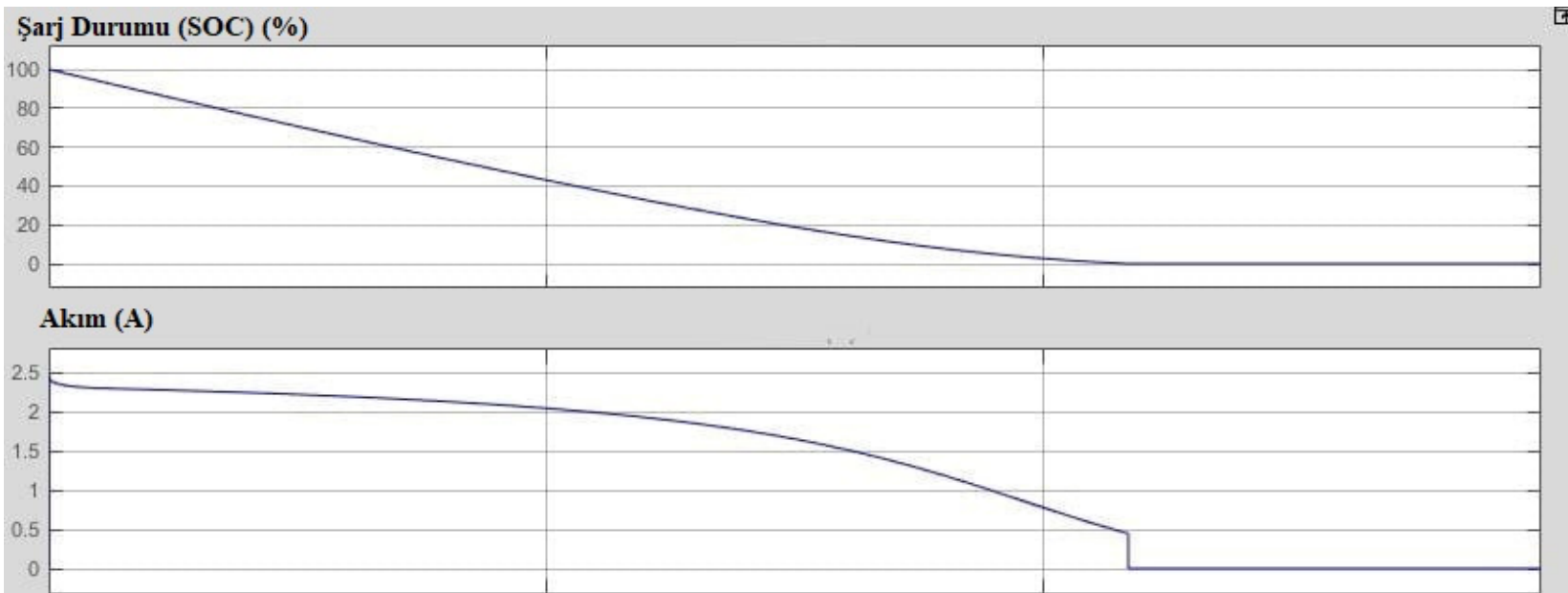

Gerilim (V)

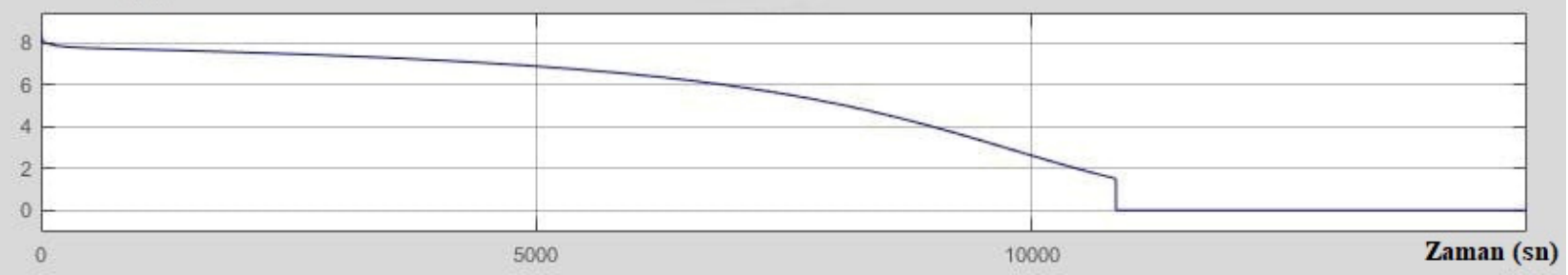

Şekil 5. Omik yük iki kat artırıldığında akım, gerilim ve şarj durumu

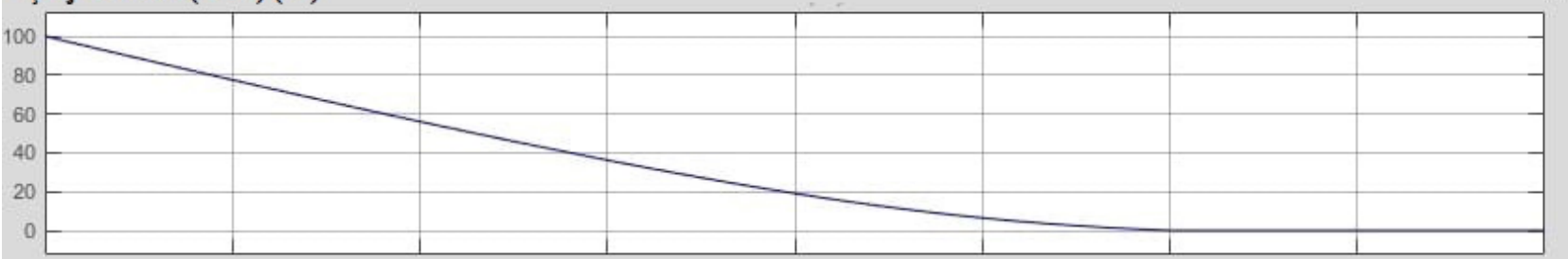

Akım (A)

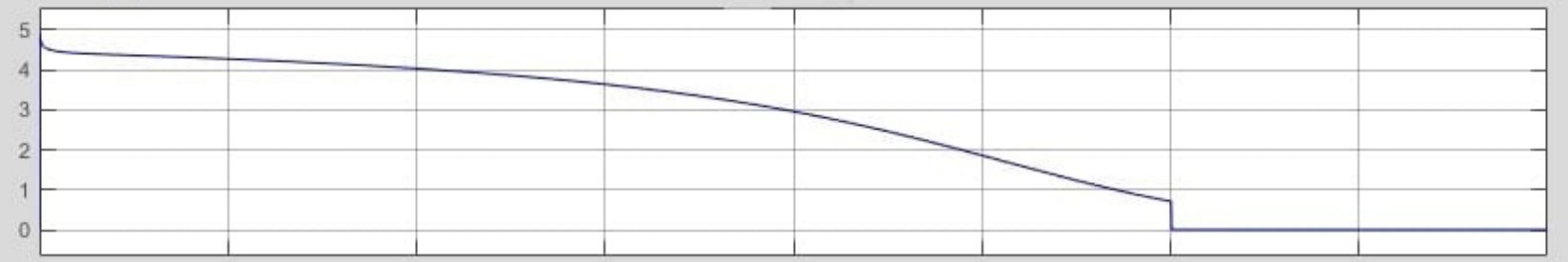

\section{Gerilim (V)}

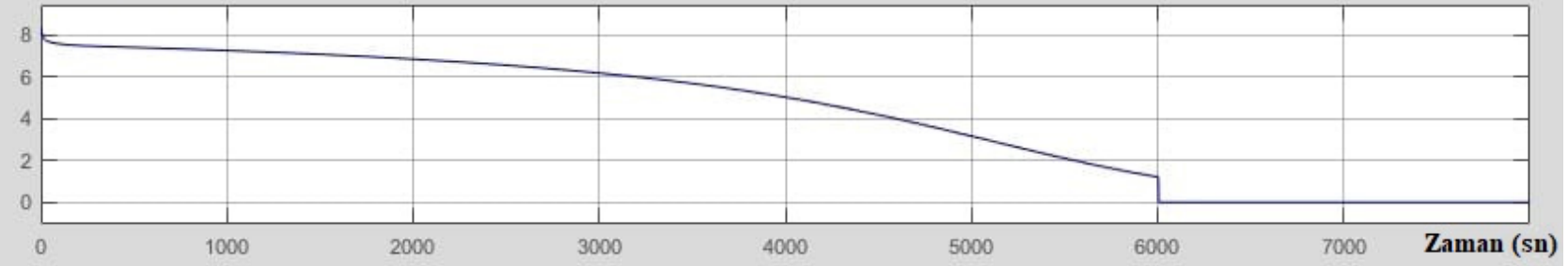

Şekil 6. Omik yük dört kat artırıldığında akım, gerilim ve şarj durumu 


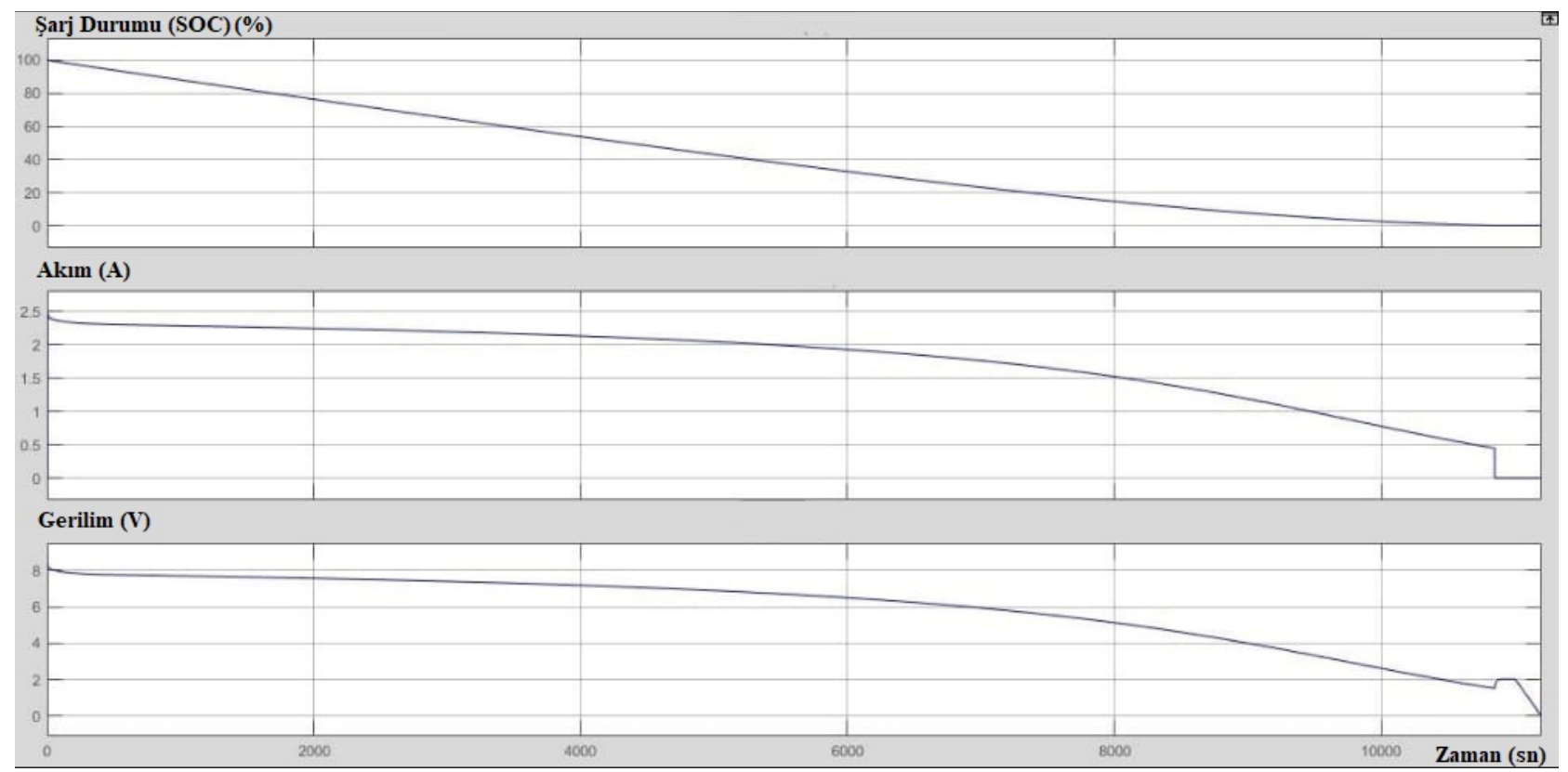

Şekil 7. Omik-indüktif yük için akım, gerilim ve şarj durumu

\section{Sonuçlar}

Elektrikli araçlar, içten yanmalı motorlu araçların sebep olduğu problemlere çözüm getirebilecek potansiyele sahiptir. Ancak yaygınlaşma istenilen hızda değildir. Elektrikli araç teknolojisinin ilerlemesini yavaşlatan en büyük sorunlar batarya kaynaklıdır. Bu yüzden çalışmalar, elektrikli araçta batarya performansı üzerinde yoğunlaşmaktadır.

Lityum iyon bataryalar; birim hücre başına en yüksek gerilim, birim kütle başına en yüksek enerji yoğunluğu, en az bakım gerektirme, yüksek çevrim ömrü özelliklerinden dolayı elektrikli araçlarda yaygın olarak kullanılmaktadırlar. Bu çalışmada elektrikli araçlarda kullanılan batarya sistemleri incelenmiş ve lityum iyon batarya paketi modellenmiştir. MATLAB/Simulink ortamında gerçekleştirilen çalışmalarda bataryanın deşarj süresinin yüke bağlı değişimi incelenmiştir. Bataryaya bağlı yük artırıldığı zaman bataryanın deşarj olma süresinin kısaldığ 1 görülmüştür.

Bu çalışmada yapılan modelleme, bir sonraki çalışmada daha büyük bir batarya paketinin modellenmesine imkân sağlayacaktır. Bunun yanı sıra, elektrikli araç için yapılan bu modelleme çalışması, hem zaman hem de maliyet tasarrufu sağlaması açısından önemlidir.

\section{Teşekkür}

Muhammed Sefa ÇETIN 100/2000 YÖK Doktora Bursu programı kapsamında desteklenmiştir.

\section{Kaynaklar}

[1] Bora Y. Elektrikli araç sistemlerinin incelenmesi. Yüksek Lisans, Yıldız Teknik Üniversitesi, İstanbul, Türkiye, 2017.

[2] Muratoğlu Y., Alkaya A. Elektrikli araç teknolojisi ve pil yönetim sistemi inceleme. Elektrik Mühendisliği 2016; (458): $10-14$.

[3] Rigan M. Batarya yönetim sistemi tasarımı. Yüksek Lisans, Kahramanmaraş Sütçü İmam Üniversitesi, Kahramanmaraş, Türkiye, 2020.

[4] Tanrısever B. Geri dönülemez noktadayız. Elektrik Mühendisliği 2016; (458): 18-22.

[5] www.bmw.com.tr/tr/topics/fascination-bmw/bmw-i-ve-e-mobilite/elektrikli-otomobil-turleri.html

[6] Özbay H., Közkurt C., Dalcalı A., Tektaş M. Geleceğin ulaşım tercihi: Elektrikli araçlar. Akıllı Ulaşım Sistemleri ve Uygulamalar1 2013; 3 (1): 34-50.

[7] Avgın M.S. Batarya şarj doluluk durumu model parametresinin G.E.P. ile tahmin edilmesi. Yüksek Lisans, Kahramanmaraş Sütçü İmam Üniversitesi, Kahramanmaraş, Türkiye, 2012.

[8] Chan By CC. The state of art of electric, hybrid, and fuel cell vehicles. Proceedings of the IEEE 2007; 95 (4): $704-718$. 
[9] Gül H.S. Elektrikli araçlar için batarya yönetim sistemi tasarımı. Yüksek Lisans, Yıldız Teknik Üniversitesi, İstanbul, Türkiye, 2018.

[10] Linden D., Reddy TB. Handbook of Batteries Third Edition. USA: McGraw-Hill, 2001.

[11] Turğut M. Elektrikli araçlar için batarya yönetim sistemi tasarımı ve geliştirilmesi. Yüksek Lisans, Karabük Üniversitesi, Karabük, Türkiye, 2018.

[12] Karabulut H. Elektrikli araçlar: İstanbul'da entegrasyon problemleri ve çözüm yolları. Yüksek Lisans, Bahçeşehir Üniversitesi, İstanbul, Türkiye, 2014.

[13] Jia Ying Y. A review on the state-of-the-art technologies of electric vehicle, its impacts and prospects. Renewable and Sustainable Energy Reviews 2015; 49: 365-385.

[14] Kurşunoğlu S. Atık çinko-karbon ve alkali pillerden çinko ve mangan geri kazanılması. Doktora, Eskişehir Osmangazi Üniversitesi, Eskişehir, Türkiye, 2009.

[15] Sayılgan E. Kullanılmış pillerden çinko ve mangan metallerinin geri kazanımı ekonomik analiz ve matematik modelleme. Doktora, Süleyman Demirel Üniversitesi, Isparta, Türkiye, 2009.

[16] Yu H., Xie T., Paszczynski S., Wilamowski B.M. Advantages of radial basis function networks for dynamic system design. IEEE Transactions on Industrial Electronics 2011; 58 (12): 5438-5450.

[17] Larminie J., Lowry J. Electric Vehicle Technology Explained. UK: John Wiley\&Sons, 2001.

[18] Özbalcı Ü., Kılıç E. Elektrikli bir aracın batarya sisteminin modellenmesi. Kahramanmaraş Sütçü İmam Üniversitesi Mühendislik Bilimleri Dergisi; (2): 64-69.

[19] Ceylan M., Sarıkurt T., Balıkçı A. Elektrikli araçlarda kullanılan lityum-iyon bataryalar için model geliştirilmesi. In:5.Enerji Verimliliği ve Kalitesi Kongresi; 23-24 Mayıs 2013; Kocaeli, Türkiye. pp. 23-24. 